Sains Malaysiana 50(2)(2021): 361-371

http://dx.doi.org/10.17576/jsm-2021-5002-08

\title{
Thermal and Mechanical Characterisation of Poly( $\omega$-Hydroxy Pelargonate): A Preliminary Study for Bioplastic
}

(Pencirian Terma dan Mekanik Poli( $\omega$-Pelargonat Hidroksi): Kajian Awal untuk Bioplastik)

\author{
Siti Faieza Abd Hadi, Muhammad Fadhli Kamaruzaman, Jumat Salimon \& Mohd Firdaus Mohd \\ YUSOFF*
}

\begin{abstract}
Poly( $\omega$-hydroxy pelargonate) or $\mathrm{P}(\omega$-OHP) is a potential biodegradable plastic which was prepared by melt condensation of its monomer ( $\omega$-hydroxy pelargonic acid). In this study, the performances of P( $\omega$-OHP) in thermal and mechanical aspects, as well as the method employed for the monomer preparation was presented. Although this type of monomer is well established for pharmaceutical and cosmetic application, its possibility to be applied in bioplastic has not been extensively studied. Previous research also showed that the monomer preparation was rather complicated, expansive, and hazardous. Thus, this study offers the safe method through chemical modification which conducted in mild condition. The monomer structure was verified by using ESI-MS at $173.1 \mathrm{~m} / \mathrm{z}$ with $92 \%$ purity. After melt-condensation process was carried out at $190{ }^{\circ} \mathrm{C}$ for $4 \mathrm{~h}$, the formation of $\mathrm{P}(\omega$-OHP) was identified by the present of methylene ester bond indicated on ${ }^{1} H$ NMR peak at $4.05 \mathrm{ppm}$. The thermal properties were analyzed by DSC, TGA, and rheometer. $\mathrm{P}(\omega-\mathrm{OHP})$ was melted at $72.8^{\circ} \mathrm{C}$ and start to degrade at $220^{\circ} \mathrm{C}$ with rheology analysis represented Newtonian flow at 80 and $180^{\circ} \mathrm{C} . \mathrm{P}(\omega$-OHP) contains $73.5 \%$ degree of crystallinity as determined by XRD with fewer amorphous area has affecting low mechanical value in hardness (31) and compressive strength (modulus $47.3 \mathrm{MPa}$, yield $1.03 \mathrm{MPa}$ ). The results suggest that $\mathrm{P}(\omega-\mathrm{OHP})$ is thermally stable and physically hard and brittle. The findings have implications for bioplastic custom and subjected to improvement via polymer blending or block co-polymerization for application flexibility.
\end{abstract}

Keywords: Bioplastic; characterization; omega hydroxy pelargonic acid; poly(omega hydroxy pelargonate)

\section{ABSTRAK}

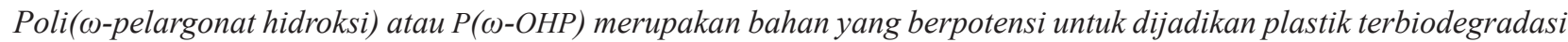
dan telah disediakan melalui kaedah penyejatan lebur terhadap monomer (asid w-hidroksi pelargonik). Kajian ini mempamerkan prestasi $P(\omega-O H P)$ terhadap aspek terma dan mekanik dan juga kaedah penyediaan monomer. Walaupun monomer jenis ini telah banyak diaplikasikan dalam bidang farmaseutik dan kosmetik, namun masih kurang kajian penggunaannya untuk aplikasi bioplastik. Kajian terdahulu turut melaporkan bahawa kaedah penyediaan monomer ini adalah sukar, mahal dan berbahaya. Maka, kajian ini menawarkan satu kaedah yang lebih selamat dilaksanakan melalui pengubahsuaian tindak balas kimia. Struktur monomer telah ditentusahkan menggunakan ESIMS pada caj $173.1 \mathrm{~m} / \mathrm{z}$ dengan ketulenan 92\%. Setelah proses kondensasi lebur dijalankan pada suhu $190{ }^{\circ} \mathrm{C}$ selama 4 jam, penghasilan $P(\omega-O H P)$ dikenal pasti dengan ikatan ester metilena yang ditunjukkan pada puncak ${ }^{1} H$ NMR pada 4.05 ppm. Sifat terma dianalisis dengan DSC, TGA dan reometer. $P(\omega-O H P)$ melebur pada suhu $72.8^{\circ} \mathrm{C}$ dan mula terurai pada suhu $220{ }^{\circ} \mathrm{C}$ serta analisis reologi menunjukkan sifat aliran Newton pada suhu 80 dan $180{ }^{\circ} \mathrm{C} . P(\omega-O H P)$ mengandungi $73.5 \%$ darjah pengkristalan yang telah ditentukan oleh XRD dengan kawasan amorfus yang rendah, ia memberi kesan terhadap nilai mekanikal yang rendah dengan kekerasan (31) dan kekuatan mampatan (modulus $47.3 \mathrm{MPa}$, purata $1.03 \mathrm{MPa}$ ). Hasil kajian menunjukkan bahawa $\mathrm{P}(\omega-\mathrm{OHP})$ adalah stabil secara terma dengan sifat fizikalnya yang keras dan rapuh. Penemuan ini menunjukkan implikasinya untuk digunakan sebagai bioplastik dan dapat ditambah baik melalui pengadunan polimer atau blok pengkopolimeran untuk kefleksibelan aplikasi.

Kata kunci: Asid omega hidroksi pelargonik; bioplastik; pencirian; poli(omega hidroksi pelargonat) 


\section{INTRODUCTION}

The demand for biodegradable plastic, which applies the middle-chain-length (MCL) aliphatic polyester, has been growing in popularity. Nevertheless, most work on aliphatic polyester seemed to place focus on shortchain-length (SCL) group of poly(hydroxy alkanoates) or (PHA) (Mehta et al. 2005). The substantial work noted for SCL-PHA group enables the mass production of several types of polymer, such as poly(lactic acid) or (PLA) and poly(hydroxy butyrate) or (PHB) (Haliru et al. 2017; Mat Uzir et al. 2015). However, such polymers have limited function and require plenty of bioplastic to substitute the vast use of petroleum-based plastic (Nehra et al. 2017). The aliphatic polyester in MCL group is defined based on its carbon chain length from 6 to 14. This group is beneficial, mainly because it displays better elastomeric characteristic, better fungal degradation rate, and tougher than SCL-PHA (Barret \& Srienc 2011; Huf et al. 2011; Mitrus et al. 2009). It also contains hydrolysable ester bond that gives it biocompatible and biodegradable attributes, which have great prospective in medical applications, cosmetics, and other wide range fields (Nair \& Laurencin 2007; Steinbuchel 2005).

One potential candidate of bioplastic in MCL group refers to poly $(\omega$-hydroxy pelargonate $)$ or $\mathrm{P}(\omega$-OHP $)$. The $\mathrm{P}(\omega-\mathrm{OHP})$ can be prepared from three various monomers, namely: $\omega$-hydroxy pelargonic acid, $\omega$-hydroxy pelargonic methyl ester, and nonanolactone (Cvetković et al. 2008; Jose et al. 2014; Liu et al. 2008; Petrović et al. 2010). These monomers can be synthesised from renewable resources, such as plant oil, starch, and glycerol either via chemical pathway or via bio-transformation (Petrović et al. 2010; Xiao et al. 2018). They may be isolated from natural resources, such as royal jelly and fresh snow, wherein the steps are rather tedious and costly (Kula et al. 1999; Tyagi et al. 2015). The chemical pathway is a practical method that uses a wide range of renewable resources with better control of targeted yield to prepare monomers (Scholz \& Khemani 2006). In particular, the ozonolysis appears to be a popular method that is used to synthesis monomers, despite its demand for massive energy to stabilise the highly-reactive ozonide compound as a result of toxicity and safety hazards during production (Fore et al. 1963; Kockritz \& Martin 2011). Alternatively, several studies have proposed better options to generate monomers, such as the multi-step of chemical reaction involving a combination of reactions including epoxidation, esterification, hydrolysis, oxidation, hydrogenation, and reduction (Rajabi et al. 2014; Sonnenberger et al. 2016; Yokota \& Watanabe 1990). Comparatively, a report stated that the modification of dicarboxylic acids (C12 and C15) through esterification/half-hydrolysis/reduction reaction is viable (Yokota \& Watanabe 1990). This method reflects practical implementation due to its mild and safe experimental condition with favourable pure high yield of the targeted monomer. The initial trials performed using dicarboxylic acid (C9), also known as azelaic acid, gave poor yield with intricate purification steps (Hadi \& Salimon 2018). Indeed, at present, general research in particular monomer production route is still in its infancy. Therefore, it is sensible to modify the synthesis route in order to improve the yield and treatment of $\omega$-hydroxy pelargonic acid to function as monomer.

This study evaluated both thermal and mechanical characteristics of a promising bioplastic candidate based on $\mathrm{P}(\omega-\mathrm{OHP})$. Apart from the general properties of $\mathrm{P}(\omega-$ OHP) mentioned earlier, the mechanical properties heavily depend on molecular weight and crystallinity degree of a particular biopolymer in reality. As such, a full investigation of $\mathrm{P}(\omega-\mathrm{OHP})$ as a preliminary study had been carried out to understand the correlation between polymer structure and material performance in light of thermal and mechanical aspects. It is integral to gather essential information for continuous improvement of material processing meant for user-end application.

\section{MATERIALS AND METHODS}

\section{MATERIALS}

Azelaic acid was purchased from Acros Organics, while barium hydroxide and sodium borohydride were obtained from Sigma Aldrich. Other chemicals were bought from Systerm. All chemicals and reagents were used without further purification.

\section{SYNTHESIS OF $\Omega$-HYDROXY PELARGONIC ACID}

The monomer was prepared in a three-step chemical reaction by using azelaic acid as the starting material. In the first step, $40 \mathrm{~g}$ of azelaic acid was reacted with excess methanol in the presence of sulfuric acid as the catalyst. Esterification was performed in Dean-Stark setup at reflux temperature for $8 \mathrm{~h}$. The mixture was cooled to room temperature and washed with saturated sodium bicarbonate $(3 \times 200 \mathrm{~mL})$ and saturated sodium chloride $(2 \times 50 \mathrm{~mL})$ prior to drying with sodium sulphate. Excess methanol was reduced under vacuum to obtain concentrated paleyellow oil of pure dimethyl azelate. In the second step, 22 $\mathrm{g}$ of dimethyl azelate was mixed with $80 \mathrm{~mL}$ of methanol, and dissolved barium hydroxide ( 0.5 equiv.) was slowly added into the mixture. The blend was stirred for $8 \mathrm{~h}$ at room temperature to allow saponification. The formed precipitate of barium salt monoester was filtered, washed with hexane, and dissolved in $300 \mathrm{~mL}$ of $1.0 \mathrm{~N} \mathrm{HCl}$. The mixture was extracted with diethyl ether $(3 \times 100 \mathrm{~mL})$. The organic layer was collected and washed with $5 \%$ potassium 
carbonate solvent $(2 \times 50 \mathrm{~mL})$, as well as with water $(1 \times$ $50 \mathrm{~mL}$ ). The organic layer was dried with sodium sulphate before it was reduced under vacuum to yield colourless liquid of monomethyl azelate. In the final step, $0.4 \mathrm{~g}$ of monomethyl azelate was suspended in $10 \mathrm{~mL}$ protic solvent of dioxane:water $(1: 1 \mathrm{v} / \mathrm{v})$ to be reduced with sodium borohydride (7 equiv.). Next, the mixture was stirred overnight and quenched with $1.0 \mathrm{~N} \mathrm{HCl}$ after freezing for $2 \mathrm{~h}$. The solution was extracted with dichloromethane and dried with sodium sulphate before reducing the excess solvent under vacuum. Once the concentrated liquid had cooled and solidified at room temperature, $\omega$-hydroxy pelargonic acid was formed.

\section{ANALYSIS OF $\Omega$-HYDROXY PELARGONIC ACID}

The synthesised compounds obtained from each reaction steps were analysed using FTIR spectrometer (model Perkin Elmer/BX). The liquid sample was prepared as a sandwich thin layer in $\mathrm{NaCl}$ plate, while $\mathrm{KBr}$ thin plate for solid sample. The range of FTIR spectrum was executed at $600-4000 \mathrm{~cm}^{-1}$.

NMR (model Bruker ARX 600) was employed to examine the molecular structure of dissolved $\omega$-hydroxy pelargonic acid in deuterated solvent, $\mathrm{CDCl}_{3}$, at $400 \mathrm{MHz}$ for proton $\left({ }^{1} \mathrm{H}\right)$ analysis.

The purity of the monomer was examined using HPLC (model Waters 1512), fitted with ELSD detector. A $20-\mu \mathrm{L}$ sample was injected and passed through $\mathrm{C} 18$ column at $35^{\circ} \mathrm{C}$ in the mobile phase of acetone:acetonitrile $(4: 1 \mathrm{v} / \mathrm{v})$ at $0.8 \mathrm{~mL} / \mathrm{min}$ of flow rate for $30 \mathrm{~min}$ isocratic mode.

The molecular mass of the monomer was verified using LC-MS (model Bruker MicrOTOF-Q) in negative mode ESI. The $10-\mu \mathrm{L}$ sample was injected and passed through $\mathrm{C} 18$ column at $35^{\circ} \mathrm{C}$ for $30 \mathrm{~min}$. The mobile phase was acetonitrile:chloroform $(1: 1 \mathrm{v} / \mathrm{v})$ with a flow rate of $0.3 \mathrm{~mL} / \mathrm{min}$. A dry heater was set at $180{ }^{\circ} \mathrm{C}$ and 2.0 bar of nitrogen gas nebuliser.

\section{PREPARATION OF POLY $(\Omega-O H P)$}

Melt condensation of $20 \mathrm{~g} \omega$-hydroxy pelargonic acid was carried out to prepare $\mathrm{P}(\omega-\mathrm{OHP})$. The reaction was stirred continuously under nitrogen gas flow at $190{ }^{\circ} \mathrm{C}$ for $4 \mathrm{~h}$. The melted polymer was then allowed to cool overnight prior to characterisation tests.

\section{ANALYSIS OF POLY $(\Omega-O H P)$}

The NMR recorded the proton $\left({ }^{1} \mathrm{H}\right)$ spectrum of dissolved $\mathrm{P}(\omega-\mathrm{OHP})$ sample in $\mathrm{CDCl}_{3}$ at $400 \mathrm{MHz}$.
Gel permeation chromatography (GPC) (model Waters) was used to determine the average number of molecular weight (Mn) and polydispersity index (PDI) of $\mathrm{P}(\omega-\mathrm{OHP})$. The $25-\mu \mathrm{L}$ of $0.5 \mathrm{mg} / \mathrm{mL}$ sample was injected in a column series that contained Styragel HR5 $(7.8 \times$ $300 \mathrm{~mm})$, Styragel HR3 $(7.8 \times 300 \mathrm{~mm})$, and Styragel HR1 $(7.8 \times 300 \mathrm{~mm})$. The THF was used as eluent with $1.0 \mathrm{~mL} / \mathrm{min}$ flow rate with a pump (model Waters 1515) and refractive index detector (model Waters 2414). The columns were kept at $40{ }^{\circ} \mathrm{C}$ and polystyrene used as a standard to calibrate the curve.

X-Ray diffractometer (XRD) (model Bruker D8Advance) was applied to analyse the crystallinity degree in $\mathrm{P}(\omega-\mathrm{OHP})$. The sample was grinded using a mortar and the powder was placed on the sample holder uniformly before it was set into XRD slot. The sample was scanned at $2 \theta$ from 2 to $50^{\circ}$ and the output was processed using the DiffracEva software.

\section{THERMAL PROPERTIES CHARACTERISATION}

Differential Scanning Calorimetry (DSC) (model DSC822 Mettler Toledo) was employed to determine the melting point of $\mathrm{P}(\omega-\mathrm{OHP})$. About 3 - $4 \mathrm{mg}$ of the sample was placed in an aluminium pan and heated at the rate of $10{ }^{\circ} \mathrm{C} / \mathrm{min}$ from 25 to $160{ }^{\circ} \mathrm{C}$ under nitrogen gas flow.

Thermogravimetric analyser (TGA) (model TGA851 Mettler Toledo) was applied to determine the thermal degradation of $\mathrm{P}(\omega$-OHP). About 4 - $5 \mathrm{mg}$ of the sample was placed on the sample holder and heated between 25 and $600{ }^{\circ} \mathrm{C}$ at a flow rate of $10^{\circ} \mathrm{C} / \mathrm{min}$ under nitrogen gas flow. Rotational rheometer (model Pisca MCR-301 Anton Paar) was used to determine the viscoelastic properties of $\mathrm{P}(\omega$-OHP $)$ at 80 and $180{ }^{\circ} \mathrm{C}$. The sample was placed to be sheared between a cone and a plate with a gap, $\mathrm{d}=0.051 \mathrm{~mm}$. The viscosity was calculated as shear strain $(\dot{Y})$, which is also the ratio of applied shear stress $(\tau)$ and applied deformation rate ranging from 0 to $1000 \mathrm{~s}^{-1}$ for 400 s. Viscosity complex, storage modulus $\left(\mathrm{G}^{\prime}\right)$ and loss modulus $\left(\mathrm{G}^{\prime \prime}\right)$ were plotted with applied angular frequency at 0.05 to $500 \mathrm{rad} / \mathrm{s}$.

\section{MECHANICAL PROPERTIES CHARACTERISATION}

Shore Scale D Durometer (model Cole-Palmer of the analogue type) was employed to assess the hardness value of $\mathrm{P}(\omega$-OHP $)$ by adhering to ASTM D 2240-91. The samples were prepared as cylinders with $8 \mathrm{~mm}$ diameter and $3 \mathrm{~mm}$ height, which were pressed with the durometer for $2 \mathrm{~s}$ on a flat surface. The outputs were recorded and the measurement was repeated five times for each of the five varying samples. 
Uniaxial compression testing was conducted using a universal testing machine (UTM) (model Instron5567) in accordance to ASTM 695-15. The samples were prepared as cylinders with $13-\mathrm{mm}$ diameter and $26-\mathrm{mm}$ height. Each sample was placed between compression anvils and was pressed with $10 \mathrm{kN}$ load at the rate of $1.6 \mathrm{~mm} / \mathrm{min}$ until $50 \%$ deformation was achieved. The measurement was repeated with other samples, and the results were generated using Instron Bluehill software.

\section{RESULTS AND DISCUSSION}

The produced monomer, $\omega$-hydroxy pelargonic acid, was prepared from the corresponding dicarboxylic acid - azelaic acid. Its preparation involved a three-step reaction, which began with esterification of azelaic acid, followed by partial hydrolysis of dimethyl azelate in both basic and acidic sequent, and lastly, completed with reduction of monomethyl azelate with sodium borohydride, as illustrated in Figure 1.<smiles>CC(C)(CC(=O)O)C(=O)O</smiles>

Azelaic acid<smiles>C=C[C@H](C)O</smiles>

I<smiles>[3H]OC(=O)C(C)(C)CC(=O)OC</smiles>
$+\mathrm{Ba}(\mathrm{OH})_{2}$<smiles>CCCCC</smiles>
$\mathrm{Ba}$<smiles>COC(=O)CC(C)(CC(C)(CC(C)(C)C(=O)O)C(=O)O)C(=O)OC</smiles><smiles>C[In+]</smiles><smiles>CC(C)(CO)CC(C)(C)C(=O)O</smiles>

$\omega$-hydroxy pelargonic acid<smiles>COC(C)C</smiles>
$\mathrm{Na}(\mathrm{BH})_{4}$

Monomethyl azelate

FIGURE 1. Synthesis of $\omega$-hydroxy pelargonic acid from azelaic acid via esterification (step I), hydrolysis of base-acid (step II) and reduction (step III)

The yield of compounds synthesised in each reaction step was considered based on the moles quantity of product formed in relation to the limiting reactant consumed during reaction as calculated based on (1):

$$
\% \text { yield }=\frac{\text { Actual moles of product formed }}{\text { Theoretical moles of product expected }} \times 100
$$

TABLE 1. The percentage of yield for individual reaction step

\begin{tabular}{lccc}
\hline \multicolumn{1}{c}{ Reaction } & Step I & Step II & Step III \\
\hline Moles of limiting reactant consumed & 0.2125 & 0.1017 & 0.0019 \\
Actual moles of product formed & 0.1721 & 0.0427 & 0.0017 \\
Theoretical moles of product expected & 0.2125 & 0.1017 & 0.0019 \\
$\%$ yield & 81 & 42 & 85 \\
\hline
\end{tabular}


Based on Table 1, the limiting reactants used were azelaic acid, dimethyl azelate, and monomethyl azelate for respective reaction step and the theoretical moles can be calculated from reaction stoichiometry. The multiply of percentage yield in every individual reaction step would give $29 \%$ overall yield of the total synthesis route. The relatively low value for overall yield obtained is attributed to the reaction that occurred in step II between barium hydroxide and dimethyl azelate. The expected conversion would be the partial saponification to form the monomethyl of barium salt. However, the reaction also produced the undesired barium salt upon completion of saponification. This salt turned into azelaic acid after it was dissolved in hydrochloric solution prior to washing with carbonate solution. In spite of unsought conversion in step II, the lower actual yield was reasonably due to the inefficiency of chemical reaction or the losses during the recovery process of product relatively.

The molecular structures of prepared compounds were analysed using FTIR as illustrated in Figure 2. The
FTIR spectrum shows a strong band of carbonyl stretch at $1739 \mathrm{~cm}^{-1}$, which signifies the formation of methyl ester in dimethyl azelate. As for the case of monomethyl azelate, the presence of two varying carbonyl groups of ester and carboxylic acid reflected a twin peak in the carbonyl stretch. The broad band that ranged from 2500 to $3300 \mathrm{~cm}^{-1}$ indicates the hydrogen-bonded dimer effect from the carboxylic group. The final spectra exhibited a single carbonyl stretch of carboxyl group at $1694 \mathrm{~cm}^{-1}$. This suggests that only ester group in the monomethyl azelate was chemo-selectively reduced to be hydroxyl. The formation of hydroxyl group can be noted from the intense and broad band stretch at $3330 \mathrm{~cm}^{-1}$. The purity of $\omega$-hydroxy pelargonic acid, which was determined using HPLC, resulted in $92 \%$ after recrystallization. This was further confirmed using ESI-mass spectroscopic analysis that displayed the mass to charge ratio $(\mathrm{m} / \mathrm{z})$ was 173.1 $\left([\mathrm{M}-\mathrm{H}]^{-}\right)$. The monomer was repetitively produced in batch to gather the yield, so as to prepare for the polymerisation step.

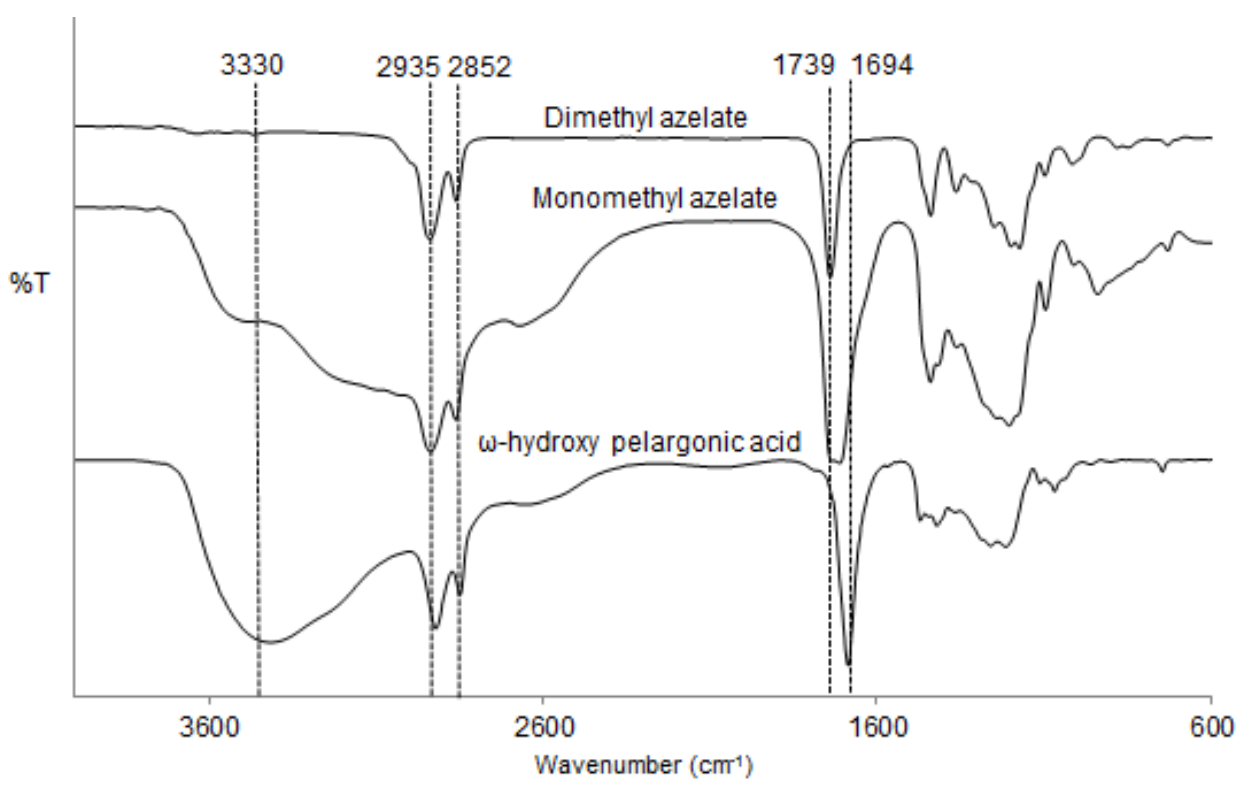

FIGURE 2. FTIR spectrum for synthesised compounds

The polymerisation was carried out via melt condensation of $\omega$-hydroxy pelargonic acid at $190^{\circ} \mathrm{C}$ for 4 $\mathrm{h}$ under nitrogen gas flow without the addition of catalyst, as described in the reaction scheme illustrated in Figure 3. 


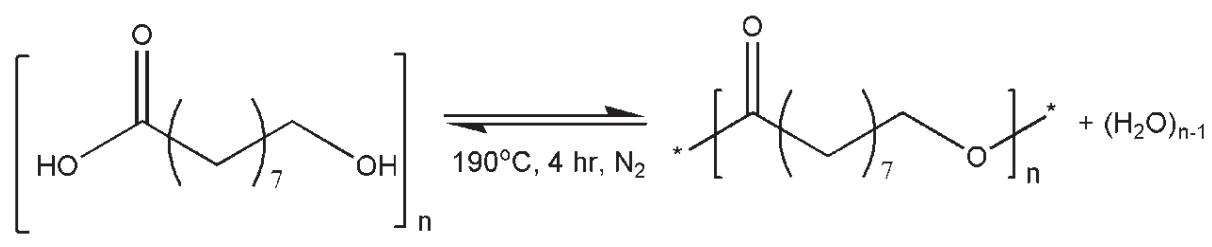

FIGURE 3. Reaction scheme for melt condensation of $\mathrm{P}(\omega-\mathrm{OHP})$

The feasibility of melt condensation was initially displayed by comparing the spectra of proton analysis between monomer and polymer, as showcased in Figure 4. The presence of a new signal at 4.03-4.07 ppm range indicates the successful formation of methylene in ester linkage during polymerisation. The absence of chemical shift at 3.64-3.67 ppm, which belonged to the terminal hydrogen of methylene connected to the hydroxyl group, signifies that the polymer has high molecular weight.

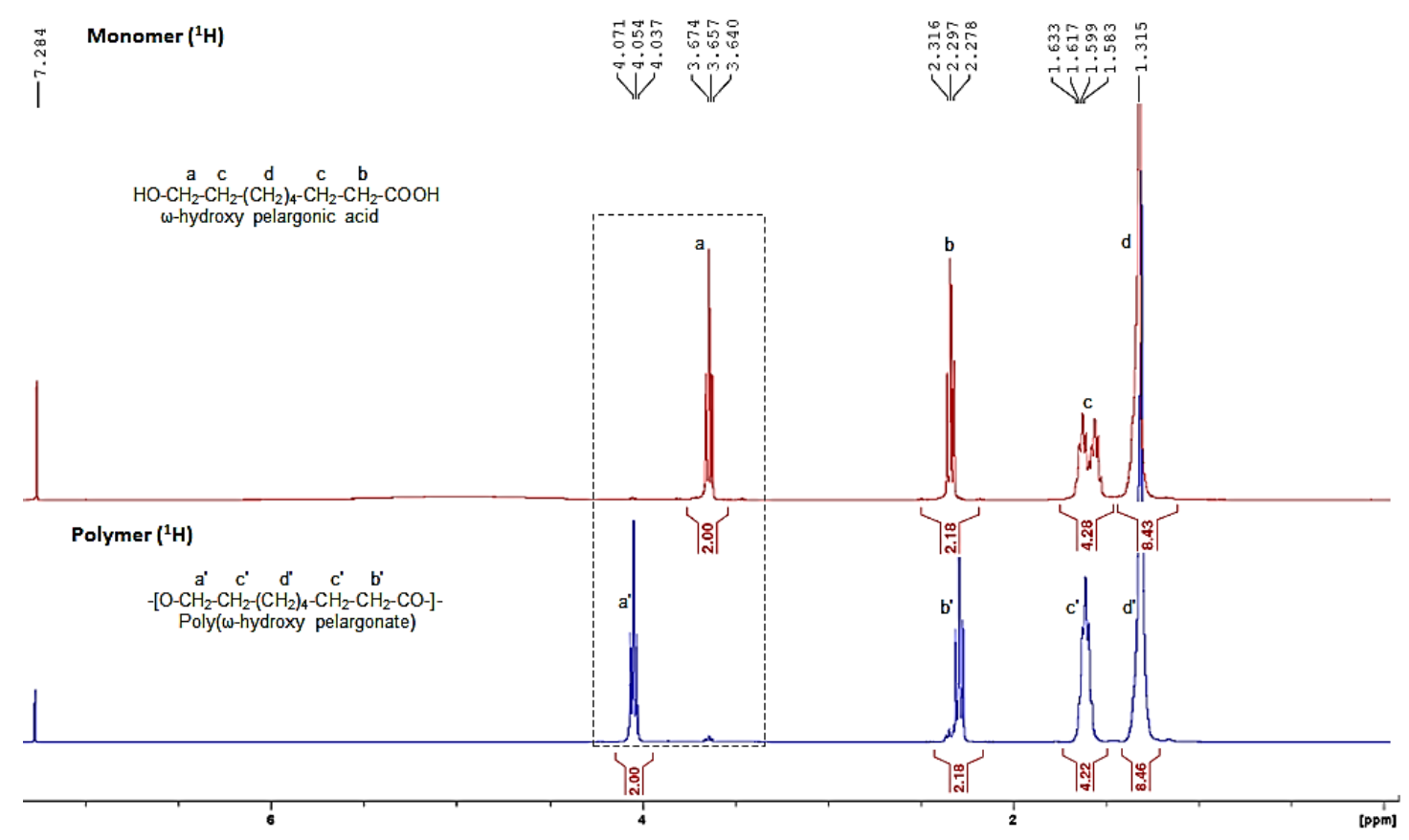

FIGURE 4. Proton ( $\left.{ }^{1} \mathrm{H}\right)$ NMR spectrum of monomer and polymer in $\mathrm{CDCl}_{3}$ at $400 \mathrm{MHz}$

Figure 5 illustrates the GPC chromatogram of the polymer that denotes molecular weight. The first elution peak corresponds to the largest molecule formed in $\mathrm{P}(\omega-\mathrm{OHP})$ with $\mathrm{Mn} 434673 \mathrm{~g} / \mathrm{mol}$ and PDI 1.3. No peak was noted for $\mathrm{Mn}>10^{4}$, which could be due to the increased step-growth rate of polymerisation as a result of high reaction temperature that led to rapid formation of bigger macromolecules. The elution peak of $\mathrm{Mn}>10^{2}$ is attributed to the small-sized molecules formed in $\mathrm{P}(\omega$ OHP). Several traces of oligomers, tetramers, and dimers with lower molecular weight were observed. The high reaction rate caused the polymer chain to grow larger at a rapid rate, thus decreasing the number of monomers. Therefore, the diffusion of the remaining smaller molecules at the interface of polymer layer appeared to be somewhat difficult (Rudin \& Choi 2013). 


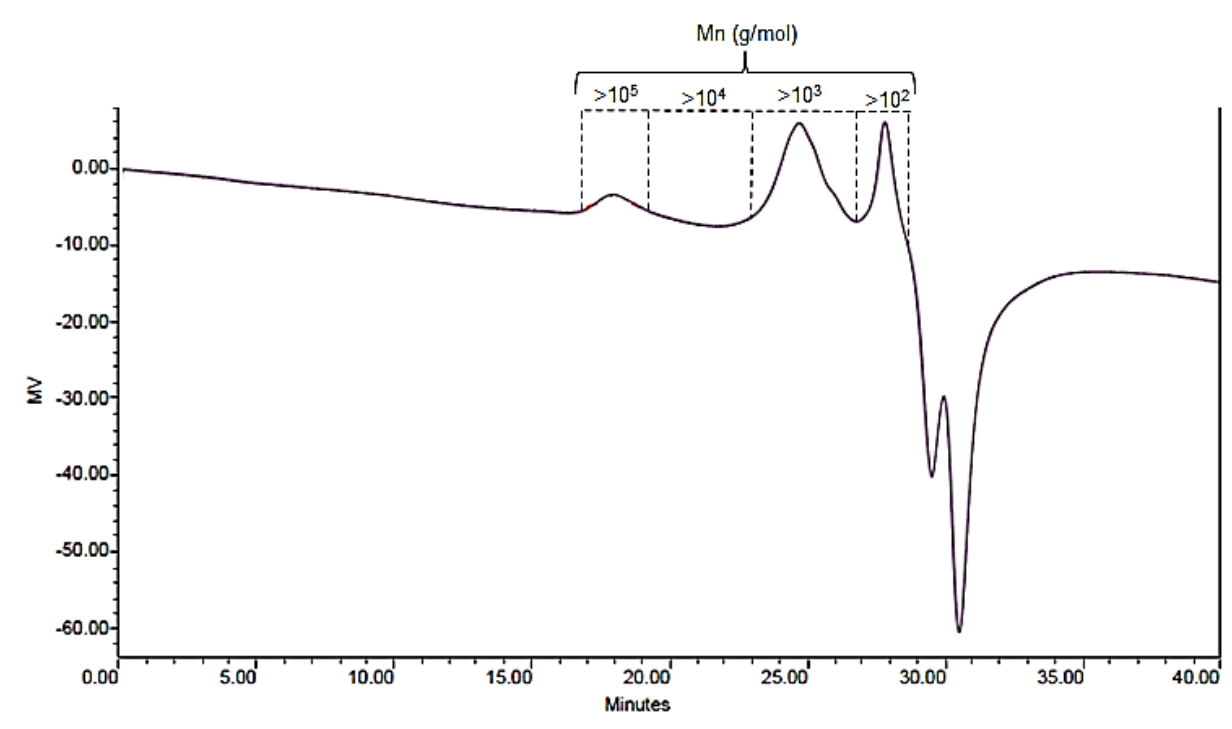

FIGURE 5. GPC chromatogram of $\mathrm{P}(\omega-\mathrm{OHP})$ in THF at $40^{\circ} \mathrm{C}$

$\mathrm{P}(\omega-\mathrm{OHP})$ shows a high degree of crystallinity at $73.5 \%$ as determined by XRD. The result was indicated a high molecular weight and high degree of crystallinity (Mn $434673 \mathrm{~g} / \mathrm{mol}, 73.5 \%$ ) as compared with the previous study (Mn $36588 \mathrm{~g} / \mathrm{mol}, 58 \%$ ). The estimation of high molecular weight with low crystallinity has been preceded due to differences in the cooling process of polymer as reported. The slow cooling rate has allowed sufficient time to fully develop the crystallization leading to highly crystalline material. These results as shown in Table 2 convey the comparison profile of physical, thermal and mechanical characteristics in relation with molecular weight $(\mathrm{Mn})$. For thermal characteristics, the parallel increment was perceived as the molecular weight of $\mathrm{P}(\omega$ OHP) multiply, the minor variation observed in melting temperature $\mathrm{TM}$ corresponds to more energy required to overcome the attraction forces in the macromolecules. Although the change in molecular weight show insignificant differences in melting temperature of $\mathrm{P}(\omega$ OHP), the substantial effect was observed on the melting profile of poly $(\omega$-hydroxy alkanoate) for different carbon chain length (C6, C9, and C12) in MCL group. Longer chains have more carbon unit per length which increase the weight and complexity of macromolecules structure, thus increasing the melting temperature significantly. In view of all the melting points which demonstrated the low value under $100{ }^{\circ} \mathrm{C}$, it helps to promote a high rate of decomposition for linear poly $(\omega$-hydroxy alkanoate) in
MCL group that could also improves its biodegradability (Flieger et al. 2003). The thermal stability of $\mathrm{P}(\omega-\mathrm{OHP})$ was evaluated by thermogravimetric analysis (TGA) technique for measuring mass changes as a function of time or temperature. Figure 6 shows the thermal curve of (TG) and its derivative (DTG) which represent the weight loss of $\mathrm{P}(\omega$-OHP $)$ heated at $10{ }^{\circ} \mathrm{C} / \mathrm{min}$. The degradation process was started at $220^{\circ} \mathrm{C}\left(\mathrm{T}_{\text {onset }}\right)$, and the initial weight loss of $13 \%$ recorded at $330{ }^{\circ} \mathrm{C}$. The temperature of $51 \%$ weight loss was recorded at $415{ }^{\circ} \mathrm{C}$ during rapid drop of weight as heating processes continue. The highest rate of weight loss was identified at $420{ }^{\circ} \mathrm{C}\left(\mathrm{T}_{\max }\right)$, and the degradation process was completed at $485^{\circ} \mathrm{C}\left(\mathrm{T}_{\text {comp. }}\right)$. The result was comparable with the previous studies as in general, the degradation of $\mathrm{P}(\omega-\mathrm{OHP})$ was occurred in dual phase. The first phase shows about 10 to $20 \%$ of weight start to deteriorate at onset temperature to approximately $350{ }^{\circ} \mathrm{C}$. The initial decrement is attributable to the degradation of low molecular weight group, including oligomers, tetramers, dimers, and impurities. In the second phase, a rapid degradation reduced most of the polymer weight up to $80 \%$ with the highest rate of loss being observed at the temperature range of $\sim 400$ to $420^{\circ} \mathrm{C}$. The major weight lost on the second phase is ascribed to a series of thermal depolymerisation of $\mathrm{P}(\omega-\mathrm{OHP})$. At higher temperatures, the loss is due to the cleavage of ester bond by end chain scission that involved a complex mechanism of random $\beta$-elimination, and $\alpha$-deprotonation in the 
macromolecule structure (Aoyagi et al. 2002; Xiang et al. 2016). Overall, $\mathrm{P}(\omega-\mathrm{OHP})$ shows a better thermal stability which offered a wide range of processing temperature above the melting point before reaching the onset point of degradation.

TABLE 2. Properties of poly( $\omega$-hydroxy alkanoate)

\begin{tabular}{|c|c|c|c|c|c|}
\hline \multirow{2}{*}{$\begin{array}{l}\text { Poly }(\omega \text {-hydroxy alkanoate }) \\
\text { Parameter }\end{array}$} & \multirow{2}{*}{$\frac{\text { PCL }(\mathrm{C} 6)}{\mathrm{i}}$} & \multicolumn{3}{|c|}{$\mathrm{P}(\omega-\mathrm{OHP})(\mathrm{C} 9)$} & \multirow{2}{*}{$\frac{\operatorname{PHDD}(\mathrm{C} 12)}{\mathrm{v}}$} \\
\hline & & ii & iii & iv & \\
\hline $\mathrm{Mn}(\mathrm{g} / \mathrm{mol})$ & $530-630000$ & 7000 & 36588 & 434673 & 36069 \\
\hline PDI & 1.1 & 1.4 & 1.7 & 1.3 & 2.9 \\
\hline Crystallinity (\%) & - & - & 58 & 73.5 & - \\
\hline \multicolumn{6}{|l|}{ Thermal } \\
\hline $\mathrm{T}_{\mathrm{m}}\left({ }^{\circ} \mathrm{C}\right)$ & $56-65$ & 69.2 & 70.5 & 72.8 & 88 \\
\hline $\mathrm{T}_{\text {onset }}\left({ }^{\circ} \mathrm{C}\right)$ & 250 & 250 & 250 & 220 & - \\
\hline $\mathrm{T}_{10-20 \%}\left({ }^{\circ} \mathrm{C}\right)$ & 382 & 300 & 354 & 330 & - \\
\hline $\mathrm{T}_{50-80 \%}\left({ }^{\circ} \mathrm{C}\right)$ & 407 & 390 & 417 & 415 & - \\
\hline $\mathrm{T}_{\max }\left({ }^{\circ} \mathrm{C}\right)$ & 410 & 400 & 422 & 420 & - \\
\hline $\mathrm{T}_{\text {comp. }}\left({ }^{\circ} \mathrm{C}\right)$ & - & 485 & 480 & 500 & - \\
\hline \multicolumn{6}{|l|}{ Rheology } \\
\hline Flow behavior & Newtonian & - & - & Newtonian & - \\
\hline $\tan \delta$ at $80^{\circ} \mathrm{C}$ & $>1$ & - & - & $>1$ & - \\
\hline $\tan \delta$ at $180{ }^{\circ} \mathrm{C}$ & $<1$ & - & - & $<1$ & - \\
\hline \multicolumn{6}{|l|}{ Mechanical } \\
\hline Hardness (Shore D) & 55 & - & - & 31 & - \\
\hline Compressive yield (MPa) & $10.3-12.5$ & - & - & 1.03 & - \\
\hline Compressive modulus (MPa) & $297-317$ & - & - & 47.3 & - \\
\hline
\end{tabular}

Key: PCL - poly(caprolactone), P( $\omega$-OHP) - poly( $\omega$-hydroxy pelargonate), PHDD - poly(12-hydroxy dodecanoate)

Ref: i. (Chae et al. 2017, Eshragi 2010; Labet \& Thielemans 2009) ii. (Liu et al. 2008) iii. (Petrovic et al. 2010) iv. (Presented results) v. (Ebata et al. 2008)

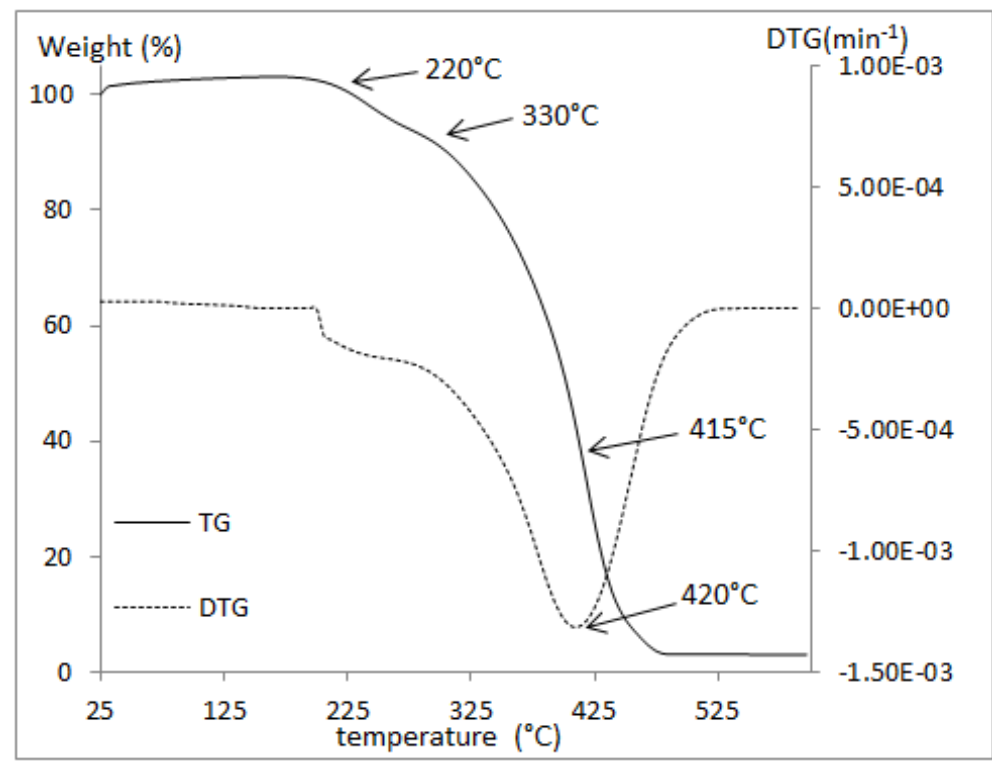

FIGURE 6. TG and DTG thermal curve for $\mathrm{P}(\omega-\mathrm{OHP})$ 
The rheology characteristics of $\mathrm{P}(\omega-\mathrm{OHP})$ was determined at 80 and $180{ }^{\circ} \mathrm{C}$ as shown in Table 3. At both temperature, $\mathrm{P}(\omega-\mathrm{OHP})$ melts exhibited Newtonian flow behaviour which represented the value of apparent viscosity $\left(\eta_{q}\right)$, independent of applied shear rate. The apparent viscosity was decreased at high temperature due to the low molecular entanglement and better chain mobility. The viscosity and elasticity property of $\mathrm{P}(\omega-\mathrm{OHP})$ can be further defined by the loss factor $(\tan \delta)$ which equivalent to the ratio of loss modulus $\left(G^{\prime \prime}\right)$ and the storage modulus $\left(G^{\prime}\right)$. The viscous material predominates the liquid-like behaviour when $G^{\prime \prime}>G^{\prime}$ or $\tan \delta>1$ meanwhile the elasticity displayed the solid-like when $\mathrm{G}^{\prime \prime}<\mathrm{G}^{\prime}$ or $\tan \delta<1$. The findings were consistent with the flow characteristic and viscoelastic property of PCL at the stated temperature, the variation might observe in the viscosity since the high chain length could increase the molecular entanglement and increasing the viscosity of material in the shear rate experiment (Ahmed et al. 2018; Chae et al. 2017). The effect of temperature on viscoelastic properties for $\mathrm{P}(\omega$-OHP $)$ was further manipulated with angular frequency $(\omega)$ of shear analysis as shown in Figure
7. The plot depicted the complex viscosity $\left(\left|\eta^{*}\right|\right)$, the storage modulus $\left(\mathrm{G}^{\prime}\right)$ and the loss modulus $\left(\mathrm{G}^{\prime \prime}\right)$ as a function of angular frequency $(\omega)$ based on (2):

$$
|\eta *|=\frac{\sqrt{G^{\prime 2}+G^{\prime \prime 2}}}{\omega}
$$

The quadratic curve of $\left|\eta^{*}\right|$ gives the minimum value of complex viscosity $\left|\eta^{*}\right|_{\min }$ and value of crossover complex viscosity $\left(\left|\eta^{*}\right|_{\mathrm{c}}\right)$ in the range of 0.1 to $0.2 \mathrm{~Pa}$.s observed at both temperature. The crossover frequency $\left(\omega_{c}\right)$ was determined at the intersection point of $G^{\prime}$ and $\mathrm{G}^{\prime \prime}$ graph indicates the phase transition of viscoelastic in the polymeric system. At this point, the characteristic of liquid-like (viscous) and solid-like (elastic) of molten $\mathrm{P}(\omega-\mathrm{OHP})$ are exactly balance. At both temperature, the storage modulus becomes larger after $\omega_{c}$ and the material predominates the solid-like behaviour. These results were found that the value of $\left(\left|\eta^{*}\right|_{c}\right)$ and $\left|\eta^{*}\right|_{\min }$ shows little fluctuation with the changes in temperature and frequency for the same polymer, this could suggest the limit of processing parameters possibly for curing and extrusion operation.

(a)

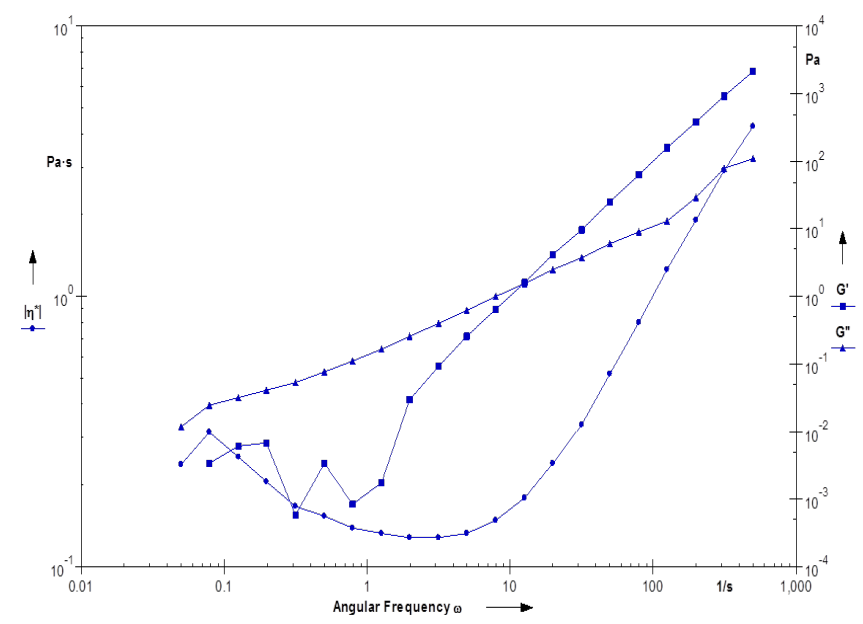

(b)

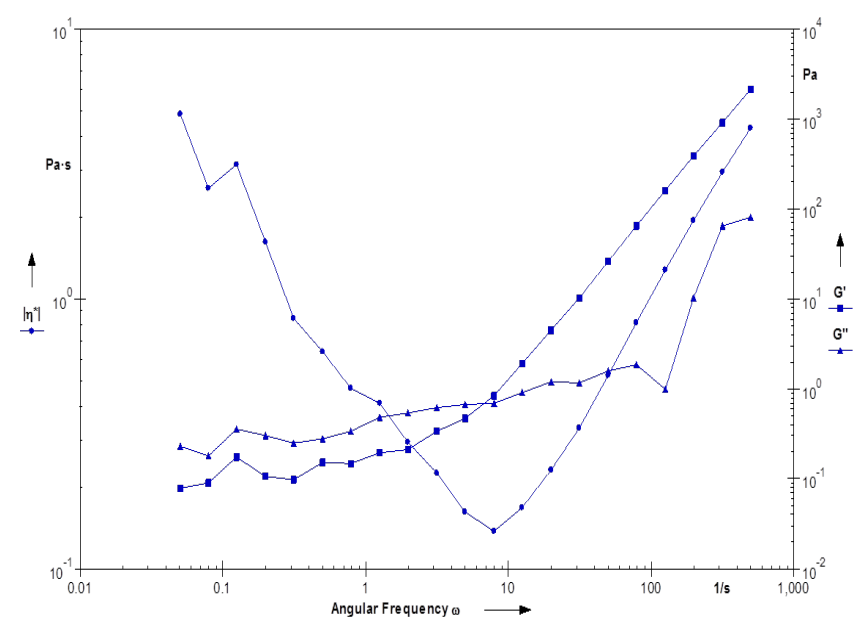

FIGURE 7. Plot of complex viscosity and moduli vs angular frequency at (a) 80 , and (b) $180^{\circ} \mathrm{C}$ 
TABLE 3. Rheology properties of $\mathrm{P}(\omega-\mathrm{OHP})$

\begin{tabular}{lllllll}
\hline $\mathrm{T}\left({ }^{\circ} \mathrm{C}\right)$ & $\mathrm{\eta}_{\mathrm{a}}(\mathrm{Pa} . \mathrm{s})$ & $\tan \delta\left(\mathrm{G}^{\prime \prime} / \mathrm{G}^{\prime}\right)$ & $\omega_{\mathrm{c}}\left(\mathrm{s}^{-1}\right)$ & $\left|\mathrm{n}^{*}\right|_{\mathrm{c}}($ Pa.s $)$ & $\omega_{\min }\left(\mathrm{s}^{-1}\right)$ & $\left|\mathrm{n}^{*}\right|_{\min }($ Pa.s $)$ \\
\hline 80 & 0.12 & 1.16 & 12.9 & 0.19 & 3.15 & 0.13 \\
180 & 0.01 & 0.13 & 6.5 & 0.16 & 7.92 & 0.14 \\
\hline
\end{tabular}

The mechanical properties were studied by performing hardness test and uniaxial compression test. The hardness test was performed by applying the Shore D Durometer that ranged between 0 and 100 . The values corresponded to three type of hardness level described as medium hard (0-30), hard (31-60) and extra hard (61$100)$ in order to measures the hardness of hard rubbers, semi-rigid plastics and hard plastics, respectively. The result shows that $\mathrm{P}(\omega-\mathrm{OHP})$ is hard polymer with low surface hardness value of 31 compared with commercial sample of PCL (Mn $42500 \mathrm{~g} / \mathrm{mol}$, Shore D hardness 55). Further observation was made with the compression test, the result found that $\mathrm{P}(\omega-\mathrm{OHP})$ demonstrate low compressive strength (modulus 47.3 MPa and yield 1.03 $\mathrm{MPa}$ ) as compared with compressive strength of PCL (Mn $91900 \mathrm{~g} / \mathrm{mol}$, modulus 297-317 MPa and yield 10.3-12.5 MPa) reported from previous study (Eshraghi 2010). The mechanical properties of $\mathrm{P}(\omega-\mathrm{OHP})$ reported in this work was declined and lower than PCL despite of the high molecular weight and crystallinity degree that could stimulate additional strengthening mechanism to the polymer. The adverse effect of hardness and compressive strength in $\mathrm{P}(\omega$-OHP $)$ was likely promoted by the segregation of low molecular weight groups (oligomers, tetramers, and dimers) causes the weak boundaries region that induced brittleness in polymer (Karger 1995).

\section{CONCLUSION}

Bioplastic based on $\mathrm{P}(\omega-\mathrm{OHP})$ was successfully prepared via melt condensation of $\omega$-hydroxy pelargonic acid. Initially, the monomer was synthesised through chemical modification of azelaic acid. The subsequent modification route generated $\omega$-hydroxy pelargonic acid with high purity $(92 \%)$ and yield $(85 \%)$. The characterisation analysis showed that $\mathrm{P}(\omega-\mathrm{OHP})$ is thermally stable and the dominant presence of low molecular weight groups in the range of $\mathrm{Mn}>\left(10^{3}-10^{2}\right) \mathrm{g} / \mathrm{mol}$ causes low mechanical properties. This $\mathrm{P}(\omega-\mathrm{OHP})$ is subjected for further modification to enhance both thermal and mechanical properties to suit the vast commercial bioplastic applications.

\section{ACKNOWLEDGEMENTS}

The financial support from the Ministry of Higher Education under MyBrain 15 sponsorship and UKM FRGS Award No. 2016-058 is gratefully acknowledged.

\section{REFERENCES}

Ahmed, J., Luciano, G., Schizzi, I., Arfat, Y.A., Maggiore, S. \& Arockia, T.L.T. 2018. Non-isothermal crystallization behavior, rheological properties and morphology of poly( $\varepsilon$-caprolactone)/graphine oxidenanosheets composite films. Thermochimica Acta 659: 96-104.

Aoyagi, Y., Yamashita, K. \& Doi, Y. 2002. Thermal degradation of poly[(R)-3-hydroxybutyrate], poly[E-caprolactone], and poly[(S)-lactide]. Polymer Degradation and Stability 76: 53-59.

Barrett, J.S.F. \& Srienc, F. 2011. Green chemistry for the production of biodegradable, biorenewable, biocompatible, and polymers. Biocatalysis for Green Chemistry and Chemical Process Development. https://doi/ abs/10.1002/9781118028308.ch13.

Chae, D.W., Nam, Y., Sung, G.A., Chang, G.C., Lee, E.J. \& Kim, B.C. 2017. Effects of molecular architecture on the rheological and physical properties of polycaprolactone. Korea - Australia Rheology Journal 29(2): 129-135.

Cvetković, I., Milić, J., Ionescu, M. \& Petrović, Z.S. 2008. Preparation of 9-hydroxynonanoic acid methyl ester by ozonolysis of vegetable oils and its polycondensation. Hemijska Industrija 62(6): 319-328.

Ebata, H., Toshima, K. \& Matsumura, S. 2008. Lipasecatalyzed synthesis and properties of poly[(12hydroxydodecanoate)-co-(12-hydroxystearate)] directed towards novel green and sustainable elastomers. Macromolecular Biosciences 8(1): 38-45.

Eshraghi, S. \& Das, S. 2010. Mechanical and microstructural properties of polycaprolactone scaffolds with onedimensional, two-dimensional, and three-dimensional orthogonally oriented porous architectures produced by selective laser sintering. Acta Biomaterial 6(7): $2467-$ 2476.

Flieger, M., Kantorová, M., Prell, A., Řezanka, T. \& Votruba, J. 2003. Biodegradable plastics from renewable sources. Folia Microbiologica 48(1): 27-44.

Fore, S.P., Ward, T.L. \& Dollear, F.G. 1963. The preparation of lauryl alcohol and 6-hydroxycaproic acid from petroselinic 
acid. Journal of the American Oil Chemists' Society 40(1): 30-33.

Hadi, S.F.A. \& Salimon, J. 2018. Preparation of $\omega$-hydroxy pelargonic acid. AIP Conference Proceedings 1940(1): 020103.

Haliru, M., Badmus, B.B., Farizul, H.K. \& Dachyar, A. 2016. Screening and production of polyhydroxybutyrate (PHB) by bacterial strains isolated from rhizosphere soil of groundnut plants. Sains Malaysiana 45(10): 1469-1476.

Huf, S., Krügener, S., Hirth, T., Rupp, S. \& Zibek, S. 2011. Biotechnological synthesis of long-chain dicarboxylic acids as building blocks for polymers. European Journal of Lipid Science and Technology 113(5): 548-561.

Jose, J., Pourfallah, G., Merkley, D., Li, S., Bouzidi, L., Leao, A.L. \& Narine, S.S. 2014. Thermoplastic polyesters and co-polyesters derived from vegetable oil: Synthesis and optimization of melt polycondensation for medium and long chain poly( $\omega$-hydroxyfatty acid)s and their ester derivatives. Polymer Chemistry 5(9): 3203-3213.

Karger, K.J. 1995. Polypropylene: Structure, Bends and Composites. London: Chapman and Hall.

Köckritz, A. \& Martin, A. 2011. Synthesis of azelaic acid from vegetable oil-based feedstocks. European Journal of Lipid Science and Technology 113(1): 83-91.

Kula, J., Smigielski, K., Quang, T.B., Grzelak, I. \& Sikora, M. 1999. Preparation of $\omega$-hydroxynonanoic acid and its ester derivatives. Journal of the American Oil Chemists Society 76(7): 811-817.

Labet, M. \& Thielemans, W. 2009. Synthesis of polycaprolactone: A review. Chemical Society Reviews 38: 3484-3504.

Liu, G., Kong, X., Wan, H. \& Narine, S. 2008. Production of 9-hydroxynonanoic acid from methyl oleate and conversion into lactone monomers for the synthesis of biodegradable polylactones. Biomacromolecules 9(3): 949953.

Mat Uzir, W., Azman, H., Akos, N.I., Nurhayati, A.Z. \& Kayathre, K. 2015. Mechanical, thermal and chemical resistance of epoxidized natural rubber toughened polylactic acid blends. Sains Malaysiana 44(11): 1615-1623.

Mehta, R., Kumar, V., Bhunia, H. \& Upadhyay, S.N. 2005. Polymer review. Journal of Macromolecular Science 45: 325-349.

Mitrus, M., Wojtowicz, A. \& Moscicki, L. 2009. Biodegradable polymers and their practical utility. In Thermoplastic Starch, edited by Janssen, L.P.B.M. \& Moscicki, L. Weinheim: Wiley-VCH. pp. 1-33.

Nair, L.S. \& Laurencin, C.T. 2007. Biodegradable polymers as biomaterials. Progress in Polymer Science 32(8): 762-798.
Nehra, K., Jamdagni, P. \& Lathwal, P. 2017. Bioplastics: A sustainable approach toward healthier environment. Plant Biotechnology: Recent Advancement and Development 15: 297-314.

Petrović, Z.S., Milić, J., Xu, Y. \& Cvetković, I. 2010. A chemical route to high molecular weight vegetable oil-based polyhydroxyalkanoate. Macromolecules 43(9): 4120-4125.

Rajabi, M., Lanfranchi, M., Campo, F. \& Panza, L. 2014. Synthesis of a series of hydroxycarboxylic acids as standards for oxidation of nonanoic acid. Synthetic Communications 44(8): 1149-1154.

Rudin, A. \& Choi, P. 2013. The Elements of Polymer Science \& Engineering. 3rd ed. Boston: Academic Press.

Scholz, C. \& Khemani, K. 2006. Degradable polymers and materials. American Chemical Society 939(1): 2-11.

Sonnenberger, S., Lange, S., Langner, A., Neubert, R.H.H. \& Dobner, B. 2016. Synthesis of ceramides Ns and Np with perdeuterated and specifically $\omega$ deuterated $\mathrm{N}$-Acyl residues. Journal of Labelled Compounds and Radiopharmaceuticals 59(12): 531-542.

Steinbüchel, A. 2005. Non-biodegradable biopolymers from renewable resources: Perspectives and impacts. Current Opinion in Biotechnology 16(6): 607-613.

Tyagi, P., Yamamoto, S. \& Kawamura, K. 2015. Hydroxy fatty acids in fresh snow samples from northern Japan: Long-range atmospheric transport of Gram-negative bacteria by Asian winter monsoon. Biogeosciences 12: 7071-7080.

Xiang, H., Wen, X., Miu, X., Li, Y., Zhou, Z. \& Zhu, M. 2016. Thermal depolymerization mechanisms of poly(3hydroxybutyrate-co-3-hydroxyvalerate). Progress in Natural Science: Materials International 26(1): 58-64.

Xiao, K., Yue, X.H., Chen, W.C., Zhou, X.R., Wang, L., Xu, L., Huang, F.H. \& Wan, X. 2018. Metabolic engineering for enhanced medium chain omega hydroxy fatty acid production in Escherichia coli. Frontiers in Microbiology 9: 139.

Yokota, T. \& Watanabe, A. 1990. Process for Producing Omega - Hydroxy Fatty Acids. Nippon Mining Company Limited. http://www.google.com/patents/EP0357865A2?cl=en. Accessed on 18 April 2016.

Center for Advanced Materials and Renewable Resources

Faculty of Science and Technology

Universiti Kebangsaan Malaysia

43600 UKM Bangi, Selangor Darul Ehsan

Malaysia

*Corresponding author; email: fir_my@ukm.edu.my

Received: 4 November 2019

Accepted: 21 July 2020 